\title{
KARAKTER PEDULI SOSIAL DALAM PEMBELAJARAN DI SDN KEBONDALEM MOJOSARI
}

\author{
Azza Maghfira \\ Universitas PGRI Adi Buana Surabaya \\ Azzamaghfira01@gmail.com \\ Apri Irianto \\ Universitas PGRI Adi Buana Surabaya \\ apriunipasby@yahoo.co.id \\ Via Yustitia \\ Universitas PGRI Adi Buana Surabaya \\ via.yustitia@unipasby.ac.id
}

\begin{abstract}
ABSTRAK
Pembelajaran lintas kurikulum berfokus pada penguatan pendidikan karakter 2013 dalam setiap materi. Namun yang terjadi masih banyak kasus penyimpangan dan akhlak. Tujuan penelitian ini adalah mendeskripsikan pengembangan karakter kepedulian sosial melalui pembelajaran di SDN Kebondalem Mojosari. Sumber data yang digunakan adalah pricipal, guru dan siswa kelas 4. Pendekatan penelitian menggunakan pendekatan penelitian kualitatif. Menggunakan teknik pengumpulan data observasi, wawancara dan dokumentasi. Teknik analisis data menggunakan pengumpulan data, reduksi data, penyajian data dan penarikan kesimpulan. Dan keabsahan datanya menggunakan teknik triangulasi. Hasil penelitian menunjukkan bahwa SDN Kebondalem Mojosari menetapkan 5 karakter. Religius, mandiri, kreatif, berintegritas dan seksi dalam berkarya. Karakter kepedulian sosial dilakukan dengan pembuatan skenario rencana pemikir, pengalaman, interaksi, komunikasi, refleksi dan inovasi. Pembelajaran karakter peduli sosial terintegrasi melalui konsep pemikir. Adanya buku yang telah disepakati antara pengasuh, guru dan siswa. Metode tutor sebaya di kelas 4 yang bertujuan untuk membantu teman yang belum memahami materi pelajaran. Ringkasan dan saran tersebut diberikan agar hasil penelitian dapat bermanfaat bagi pembaca khususnya bagi pendidik yang ingin mengembangkan karakter peduli sosial melalui pembelajaran di sekolah.
\end{abstract}

Kata kunci: Pendidikan karakter, Karakter kepedulian sosial, pembelajaran di SD

\begin{abstract}
Learning across the curriculum focuses on strengthening 2013 character education in every material. But that happened there are still many cases of irregularities and moral character. The purpose of this research was to describe the caracter development of social care through learning in SDN Kebondalem Mojosari. the data source use is the pricipal, the teachers and the students of class 4. Approach to research using qualitative research approach. Using data collection techniques of observation, interview and documentation. Technique of data analysis using data collection, reduction of data, display data and the withdrawal of the conclusion. And validity of the data using triangulation techniques. The results showed that SDN Kebondalem Mojosari set 5 characters. Religius, independent, creative, integrity and section of the work. The caracter of social care is done by the creation of a scenario plan thinkers, experience, interaction, communication, reflection and innovation. The character of social care integrated learning through the concept of thinkers. The existence of a book which has been agreed between caregives, teachers and students. Peer tutor methods in class 4 that aims to help a friend who did not understand the subject matter. Summary and advice is given so thar research can be useful for the reader, especially for educators who want to develop the character of social care through learning in school.
\end{abstract}

Keywords : Character education, The caracter of social care, Elementary school learning

\section{PENDAHULUAN}

Pendidikan merupakan unsur yang sangat penting dalam kehidupan manusia, dengan harapan pendidikan mampu membuat perubahan yang lebih baik lagi bagi manusia dan dapat memajukan bangsa. Pendidikan dapat mengarahkan manusia dari yang awalnya buta informasi menjadi orang yang mengetahui banyak hal, 
karena pendidikan merupakan upaya untuk membangun kecerdasan manusia baik kognitif, afektif atau psikomotorik. Berbicara tentang pendidikan, sudah tentu tak lepas dari upaya mengembangkan sumber daya manusia yang berkualitas, dan manusia yang berkualitas itu dapat dilihat dari segi pendidikan. Sebuah produk yang ingin dihasilkan dari proses pendidikan ialah berupa lulusan-lulusan yang mampu menghadapi dan melaksanakan perannya di masa yang akan datang (Yustitia \& Wardani, 2017). Pada dasarnya, tumbuh kembangnya peserta didik bergantung dari dua unsur yang saling mempengaruhi, yakni bakat yang tertanam sejak ia lahir dan lingkungan yang dapat mempengaruhi bakat itu hingga berkembang.

Hakikat pendidikan adalah mengembangkan manusia seutuhnya (Santika, 2017). Melalui pendidikan yang tidak hanya mengembangkan kognitif dan psikomotor saja, namun afektif juga sangat diperlukan. Di era globalisasi yang perkembangannya semakin pesat ini mempengaruhi gaya hidup manusia yang individualisme dan acuh tak acuh. Manusia yang berkarakter baik adalah mereka yang memiliki akhlak, moral dan budi pekerti yang baik. Hal itu sesuai dengan tujuan pendidikan Nasional yang telah ditetapkan pada Undang-Undang Nomor 20 tahun 2003 tentang Sistem pendidikan Nasional, Pasal 3. "Pendidikan nasional berfungsi mengembangkan kemampuan dan membentuk watak serta peradaban bangsa yang bermartabat dalam rangka mencerdaskan kehidupan bangsa, bertujuan untuk berkembangnya potensi peserta didik agar menjadi manusia yang beriman dan bertakwa kepada Tuhan Yang Maha Esa, berakhlak mulia, sehat, berilmu, cakap, kreatif, mandiri, dan menjadi warga negara yang demokratis serta bertanggung jawab." Membicarakan karakter adalah hal yang paling mendasar. Pendidikan karakter memiliki makna yang lebih tinggi daripada pendidikan moral, karena tidak hanya memberikan pengajaran tentang benar dan salah, namun mencakup pembiasaan sikap yang baik sehingga dapat berperilaku sesuai dengan aturan (Putri, 2018; Munawwaroh, 2019; Cahyani, 2020).

Dalam dunia pendidikan terdapat tiga ranah yang harus dikuasai oleh peserta didik yakni ranah kognitif, afektif dan psikomotorik. Namun pada kenyataannya ranah yang masih terlihat menonjol adalah ranah kognitif dan psikomotorik. Peserta didik mahir dalam pembelajaran, mendapat nilai yang bagus, namun mereka lupa bahwa ranah afektif juga harus ada. Sikap dan moralitas terabaikan (Santika, 2021).

Akhir-akhir ini di dalam kehidupan berbangsa dan bernegara, jiwa nasionalisme rakyat Indonesia semakin memudar. Dengan ditandai sikap individualisme, hedonisme, dan terorisme yang semakin marak. Rasa peduli antar sesama sudah terkikis. Menganggap orang yang memiliki harta dan jabatan adalah orang yang patut dihormati dan disegani sedangkan yang hanya rakyat biasa tidak mendapatkan keadilan dan hanya dipandang sebelah mata. Dapat dilihat dari beberapa kasus yang ada pada siswa sekolah dasar, setiap perbedaan di dalam kelas menjadi bumerang atau permasalahan yang sering terjadi. Siswa yang latarbelakang keluarganya dari golongan orang berada tidak mau bergaul dengan teman yang tidak setara dengannya. Begitupula sebaliknya, siswa yang latarbelakang dari keluarga sederhana selalu merasa minder dan sering menyendiri. Rasa peduli antar sesama dibedakan, selalu menganggap dirinya unggul sehingga tidak mau berbagi dengan teman, saling mengejek dan menjatuhkan juga termasuk permasalahan pada siswa (Rezkita \& Wardani, 2018). Selain itu, hal yang masih sering terjadi dalam dunia pendidikan adalah siswa yang kecanduan rokok, 
terlibat narkoba, mengambil barang orang lain bahkan menonton film dewasa bersama dengan siswa lain. Hal ini sangat tidak pantas terlebih terjadi pada siswa sekolah dasar yang kewajibannya hanya belajar dan belajar, sikap dan kebiasaan tersebut bukan asli karena keinginannya, tetapi karena lingkungan yang menyebabkan siswa tersebut memiliki keinginan untuk berbuat hal yang tidak baik. Terkadang, dari pihak keluarga kurang memperhatikan putra putrinya, mengangap bahwa sekolah adalah satu satunya pembentuk karakter siswa, padahal dari pihak keluarga dan lingkungan rumah juga sangat berpenagruh terhadap sikap dan kebiasaan siswa. Penerapan pendidikan karakter tidak hanya melibatkan siswa dan guru, namun peran orang tua dan lingkungan sangat berpengaruh. Dalam hal ini, keluarga memiliki peranan yang sangat penting dalam pembentukan sikap putra dan putrinya. Didikan dari keluarga serta kebiasaan orang tua terhadap putra putrinya berpengaruh besar terhadap kebiasaan sehari-hari. Namun sikap seseorang dapat berkembang manakala dapat pengaruh baik dari dalam maupun dari luar.

Melihat perkembangan zaman yang berdampak pada menurunnya sikap peduli antar sesama, maka yang harus diperbaiki terlebih dahulu adalah dalam dunia pendidikan khususnya pada siswa sekolah dasar. Koesoema (2007) mengemukakan bahwa pendidikan karakter menjadi semakin mendesak untuk diterapkan dalam lembaga pendidikan, mengingat berbagai macam perilaku yang non-edukatif kini telah merambah dalam lembaga pendidikan. Oleh karena itu, karakter perlu ditanamkan sejak dini agar anak punya dasar karakter yang baik sehingga tida mudah terpengaruh oleh lingkungan buruk.P embelajaran di kurikulum 2013 menitikberatkan pada penguatan pendidikan karakter di setiap materinya (Via, 2017; Safitri, 2018; Fanny, 2019). Sebenarnya pendidikan karakter sudah ada sejak dulu, namun memang masih beberapa sekolah yang sudah menerapkan kurikulum 2013, siswa di tuntut untuk mandiri dan kreatif. Berbagai penyimpangan yang terjadi menunjukkan bahwa adanya penurunan moral dan karakter (Santika, 2018). Sehingga pemerintah berusaha mengatasi masalah tersebut khususnya yang di dalam dunia pendidikan yakni dengan menjadikan pendidikan karakter sebagai hal yang utama. Penguatan pendidikan karakter juga diharapkan dapat terlaksana dengan baik. Nilai Pendidikan karakter peduli sosial ada 18, salah satunya yakni pendidikan karakter peduli sosial. Model pengintegrasian karakter peduli sosial dapat dilakukan dengan 3 cara, yakni melalui program pengembangan diri, integrasi pada pembelajaran dan melalui budaya sekolah. Dalam penelitian ini, indikator yang diambil oleh peneliti dari beberapa sumber adalah: (1) Meminjamkan alat kepada teman yang tidak membawa / tidak punya; (2) Membantu teman yang tidak faham materi pembelajaran; (3) Membangun kerukunan warga kelas; (4) Berempati kepada sesama teman kelas; (5) Bermain dan belajar bersama

Berdasarkan latar belakang yang telah dijabarkan di atas, maka peneliti melakukan penelitian dengan judul "Pengembangan Pendidikan Karakter Peduli Sosial Melalui Pembelajaran di SDN Kebondalem Mojosari”.

\section{METODE PENELITIAN}

Penelitian ini menggunakan pendekatan penelitian kualitatif yang menyajikan data menggunakan kata. Hal ini sejalan dengan pedapat Sugiyono (2015) metode penelitian kualitatif adalah metode penelitian yang berlandaskan pada filsafat postpositivisme, digunakan untuk meneliti pada kondisi obyek yang alamiah, (sebagai lawannya adalah eksperimen) dimana peneliti adalah sebagai instrumen kunci, pengambilan 
sampel sumber data dilakukan secara purposive dan snowball, teknik pengumpulan dengan triangulasi (gabungan), analisis data bersifat induktif/kualitatif, dan hasil penelitian kualitatif lebih menekankan makna daripada generalisasi. Penelitian ini mendiskripsikan pendidikan karakter peduli sosial melalui pembelajaran pada peserta didik kelas 4 yang dilaksanakan di SDN Kebondalem Mojosari.

Dengan pendekatan penelitian kualitatif maka peneliti akan mendeskripsikan data menggunakan kata dan gambar. Data dalam penelitian ini adalah data hasil observasi, data hasil wawancara, dan data hasil dokumentasi. Sumber data adalah kepala sekolah, guru dan murid serta aktivitas epserta didik dalam pembelajaran di kelas 4. Tempat kegiatan pembelajaran yaitu ruang kelas IV SDN Kebondalem Mojosari, dan dokumentasi berupa foto dan Skenario pembelajaran. Pengumpulan data dilakukan dengan menggunakan teknik observasi, wawancara, dan dokumentasi. Sugiyono (2018:294) menjelaskan Uji keabsahan data dalam penelitian kualitatif meliputi uji kredibilitas data (validitas internal), uji depenabilitas (reliabilitas) data, uji transferabilitas (validitas eksternal/generalisasi), dan uji komfirmabilitas (objektivitas). Namun yang utama adalah uji kredibilitas data. Uji kredibilitas dilakukan dengan perpanjangan pengamatan, meningkatkan ketekunan, triangulasi, diskusi dengan teman sejawat, membercheck, dan analisis kasus negatif. Penelitian ini menggunakan uji kredibilitas dengan dengan triangulasi. Terdapat triangulasi sumber, triangulasi teknik, dan waktu. Peneltian ini menggunakan Triangulasi teknik dengan menggabungkan observasi, wawancara dan dokumentasi kemudian ditarik kesimpulan.

\section{HASIL DAN PEMBAHASAN}

Peneliti mengumpulkan data tentang pengembngan karakter peduli sosial melalui pembelajaran di SDN Kebondalem Mojosari. Peneliti mengumpulkan data menggunakan teknik wawancara, observasi dan dokumentasi. Berdasarkan hasil wawancara, observasi dan dokumentasi diperoleh data tentang pengembangan karakter peduli sosial melalui pembelajaran di SDN Kebondalem Mojosari. Fokus peneliti melakukan observasi karakter peduli sosial di kelas 4. Dengan wawancara kepalasekolah, guru kelas 4 dan siswa. Hasil dari pengembangan karakter peduli sosial melalui pembelajaran adalah:

\section{Pengembangan Karakter Peduli Sosial Melalui Pembelajaran di SDN Kebondalem Mojosari}

Fokus penelitian peneliti adalah karakter peduli sosial melalui pembelajaran. Untuk pembelajaran di dalam kelas, guru mengembangkan karakter peduli sosial dengan cara membuat skenario pembelajaran. Skenario tersebut sama dengan RPP namun pembuatannya lebih mudah. Kepala sekolah menetapkan skenario pembelajaran untuk dibuat oleh guru di setiap pembelajaran. metode pengajaran menggunakan konsep MIKIR, yakni Mengalami, Interaksi, Komunikasi, Inovasi dan Refleksi. Skenario tersebut berisi Kompetensi Dasar, Indikator, Tujuan, dan Langkah pembelajaran yang sesuai dengan konsep MIKIR. Dalam satu skenario, 5 konsep tersebut ditulis muatan pelajarannya secara terpisah. Misalnya pada pembelajaran 1 dengan muatan pelajaran Bahasa Indonesia, IPA dan PPKN. Setiap muatan pelajaran harus ada 5 konsep mikir. "Mengalami", siswa diminta untuk mengamati, membaca, melihat, memegang, dll. Siswa diharapkan dapat mengalami langsung dalam pembelajaran tersebut. "Interaksi", disini yang dimaksud dengan interaksi adalah berdisuksi antar 
kelompok. Jadi pembelajaran di kelas 4 adalah pembelajaran secara berkelompok, setiap bulan guru mengacak kelompok tersebut. Dengan tujuan agar semua dapat berteman dengan siapapyn tanpa membeda-bedakan.

Pada konsep interaksi, guru memberikan permasalahan yang harus didiskusikan bersama kelompoknya. Kemudian dilanjutkan pada konsep 'Komunikasi'. Komunikasi ini menekankan siswa untuk presentasi dari apa yang telah di diskusikan kelompok. Kemudian kelompok lain menanggapi presentasi temannya. Siswa yang presentasi di setiap kelompok bergantian. Saling menanggapi dengan sikap dan cara yang benar. Guru selalu memantau diskusi dan presentasi ssiwanya. Siswa yang tidak aktif akan diberi pertanyaan oleh guru terkait dengan materi yang telah di diskusikan. Selanjutnya yakni "Inovasi", di dalam konsep inovasi, guru memberikan tugas individu kepada siswa. Tugas individu ini memuat 1 pelajaran yakni tentang materi yang telah dibahas. Setelah siswa diberi tugas individu, masuk ke konsep yang terakhir yakni "Refleksi", yang dimaksud dengan refleksi disini adalah kesimpulan pembelajaran dari awal sampai akhir. Namun tetap dalam satu muatan pelajaran, biasanya guru menulis kesimpulan atau rangkuman di papan tulis untuk di tulis oleh siswa di buku tulisnya. Refleksi ini menuntut siswa untuk mengulang kembali apa yang telah diajarkan. Sebelum guru menulis di papan tulis, bisanya guru memberikan pertanyaan terlebih dahulu kepada siswa. Untuk mengukur sejauh mana mereka paham dengan materi yang telah diajarkan. Kemudian dengan jembatan peralihan, guru masuk ke muatan pelajaran selanjutnya. Terkadang, guru melakukan refleksi di akhir pembelajaran setelah semua muatan selesai diajarkan.

\section{Kendala yang dialami dalam Pembentukan Karakter Peduli Sosial di SDN Kebondalem Mojosari}

Penelitian pengembangan karakter peduli sosial melalui pembelajaran ini tak lepas dari suatu masalah atau kendala. Kendala tersebut dapat terjadi karena berbagai macam faktor. Kendala tersebut bukanlah suatu hal yang diinginkan oleh setiap orang. Namun, tak bisa dipungkiri bahwa setiap kegiatan dalam penelitian tentu semakin sedikit atau banyak akan menemukan suatu kendala. Tergantung bagaimana cara atau solusi yang bisa diterapkan dalam mengatasi atau mengantisipasi terjadinya suatu kendala.

Kendala yang dialami dalam pengembangan karakter peduli sosial adalah Dalam pengembangan karakter peduli sosial melalui pembelajaran yang dilaksanakan di SDN Kebondalem Mojosari, kendala yang sering terlihat adalah mindset siswa yang sudah tertanam bahwa teman yang nakal akan selamanya nakal, teman yang pintar akan selamanya pintar. Terkadang siswa di kelas 4 tidak mau bergaul dengan teman yang terlalu pendiam ataupun terlalu nakal. Siswa yang nakal pun susah untuk dinasihati. Ia seringkali terlihat mengganggu temannya. Selain itu, karakter di sekolah memang terlihat baik. Namun pada kenyatannya kebiasaan baik itu hanya dilakukan di sekolah saja. Saat mereka berada di luar sekolah, karakter mereka sudah berubah, dari yang di sekolah diam menjadi sangat nakal. Dari yang di sekolah tidak bertengkar menjadi bertengkar dan saling olok mengolok. Peneliti telah mendapati peristiwa yang terjadi di kelas 4 namun diluar sekolah. Dua siswa laki-laki bertengkar sampai salah satu mengalami patah tulang di bagian tangan kirinya. Hanya karena masalah kecil namun mereka sampai bertengkar sampai mengakibatkan hal yang fatal. Sikap seperti ini tidak mencerminkan siswa yang berkarakter, padahal di sekolah mereka berdua selalu menjunjukkan rasa peduli antar teman dan tidak bertengkar. Mengapa saat diluar 
sekolah justru mereka bertengkar sampai fatal? Ini termasuk kendala besar dalam menanamkan karakter peduli sosial hanya berlaku di sekolah.

Menurut kepala sekolah, kendala yang dialami dalam pengembangan karakter berada di sisi sosial yakni mengelompok. Beberapa siswa ada yang tidak mau bergaul dengan teman sebayanya apabila teman tersebut keadaan sosialnya tidak sederajat. Selain itu, untuk sosial di bidang nasional mereka para siswa mau mengikuti kegiatan upacara hari pahlawan atau hari besar tanpa ada perbedaan, namun untuk kegiatan sosial keagamaan seperti maulud nabi, siswa yang beragama non muslim kadang iri. Ia mau hadir namun bukan termasuk agamanya, namun apabila tidak hadir ia akan diberi alfa oleh guru.

\section{SIMPULAN}

Pengembangan karakter peduli sosial melalui pembelajaran di SDN kebondalem termuat dalam skenario yang ditetapkan oleh SDN kebondalem, skenario tersebut dibuat oleh guru di setiap pembelajarannya. Konsep yang termuat dalam skenario adalah konsep MIKIR. Yakni Mengalami, interaksi, komunikasi, inovasi dan refleksi. Dimana dalam mengalami, siswa dituntut untuk berepran langsung dalam pembelajaran. Seperti mengamati, menulis, membaca, dll. Interaksi, siswa diminta untuk berdiskusi dengan teman sekelompoknya. Dalam berdiskusi, setiap kelompok memiliki tutor yakni teman sekelompok yang bertugas untuk membantu temannya yang tidak faham materi pelajaran. Hal ini dinamakan tutor sebaya. Kemudian komunikasi, di dalam komunikasi siswa diminta untuK mempresentasikan hasil diskusi kelompok di depan kelas. Inovasi, guru memberikan tugas individu untuk siswa dan terakhir refleksi yakni kesimpulan dari pembelajaran. Skenario dibuat tiap mata pelajaran. Selain itu, guru membuat buku pelanggaran untuk siswa yang melanggar kesepakatan kelas. Pada indikator pertama yakni meminjamkan alat tulis kepada teman yang tidak membawa atau tidak punya, tidak ada kendala yang nampak karena semua siswa saling meminjamkan alat tulis apabila ada teman yang tidak membawa atau tida punya. Pada indikator kedua yakni membantu teman yang tidak faham materi pelajaran, metode tutor sebaya sangat bagus diterapkan, namun kendalanya adalah kurangnya waktu pada saat tutor berusaha membantu teman yang tidak faham materi pelajaran. Karena siswa yang tidak faham materi pelajaran membutuhkan banyak waktu untuk tutor menjelaskan ulang setelah guru menjelaskan. Di indikator yang ketiga yakni membangun kerukunan warga kelas, kendala yang dialami adalah masih seringnya siswa berkelahi atau saling jail satu sama lain yang mengakibatkan temannya menangis. Indikator keempat yakni berempati kepada sesama teman kelas, tidak ada kendala karena rasa empati siswa sangat terlihat. Meskipun siswa banyak yang berkelahi dan usil, namun mereka tetap mau meminta maaf tanpa disuruh. Jika ada teman yang menangis pun siswa lain peduli untuk menghibur dan menenangkan agar tidak menangis lagi. Kendala yang dialami dalam Indikator kelima, bermain dan belajar bersama yakni pembelajaran di kelas 4 tidak selalu ada permainan. Terkadang guru mengajar tidak sesuai dengan skanario pembelajaran, masuk hanya memberikan tugas kemudian ditinngal sehingga siswa banyak yang bergurau sendiri di dalam kelas.

\section{DAFTAR PUSTAKA}

Cahyani, R. P. (2020). Pembentukan Karakter Mandiri Melalui Pembelajaran Tematik di SDN Kebondalem Mojosari. Didaktis: Jurnal Pendidikan dan Ilmu Pengetahuan, 20 (3).

Fanny, A. M. (2019, March). Analysis Of Pedagogical Skills And Readiness Of Elementary School Teachers In Support Of The Implementation Of The 2013 Curriculum. In International 
Conference on Bussiness Law and Pedagogy (Vol. 1, No. 1, pp. 59-63).

Koesoema Doni A. (2007). Pendidikan Karakter Strategi Mendidik Anak di Jaman Global. Jakarta: PT Grasindo.

Munawwaroh, A. (2019). Keteladanan Sebagai Metode Pendidikan Karakter. Jurnal Penelitian Pendidikan Islam,[SL], 7(2), 141-156.

Putri, D. P. (2018). Pendidikan Karakter pada anak sekolah dasar di era digital. AR-RIAYAH: Jurnal Pendidikan Dasar, 2(1), 37-50.

Rezkita, S., \& Wardani, K. (2018). Pengintegrasian Pendidikan Lingkungan Hidup Membentuk Karakter Peduli Lingkungan Di Sekolah Dasar. Trihayu, 4(2), 259008.

Permendiknas Nomor 20 tahun 2003 tentang Sistem pendidikan Nasional, Pasal 3.

Sugiyono, 2015. Metode Penelitian Pendidikan Pendekatan Kuantitatif, Kualitatif, dan $R \& D$. Bandung: Alfabeta .

Sugiyono (2018). Metode Penelitian Pendidikan Pendekatan Kuantitatif, Kualitatif, dan $R \& D$. Bandung: Alfabeta.

Via, Y. (2017). Kemampuan Analisis Mahasiswa PGSD Terhadap Tujuan Pembelajaran Dimensi
Safitri, D. D. (2018). Managing school based on character building in the context of religious school culture (Case in Indonesia). Journal of Social Studies Education Research, 9(4), 274294.

Santika, I. G. N. (2021). Pendidikan Kewarganegaraan (Studi Komparatif Konstitusi Dengan UUD 1945). Jawa Tengah: Lakeisha.

Santika, I. G. N. (2018). Strategi Meningkatkan Kualitas SDM Masyarakat Padangsambian Kaja Melalui Pendidikan Karakter Berbasiskan Kepedulian Lingkungan Untuk Membebaskannya Dari Bencana Banjir. Widya Accarya. 9 (2).

Santika, I Gusti Ngurah. 2017. Kepala Sekolah Dalam Konsep Kepemimpinan Pendidikan: Suatu Kajian Teoritis. Widya Accarya. 7 (1).

Kognitif pada Mata Kuliah Perencanaan Pembelajaran. Jurnal Ilmu Pendidikan, 7(1).

Yustitia, V., \& Wardani, I. S. (2017, August). Authentic assessment analysis based on the KKNI curriculum in applied statistics learning. In Ideas for 21 st Century Education: Proceedings of the Asian Education Symposium (AES 2016), November 22-23, 2016, Bandung, Indonesia (p. 55). Routledge. 